ISSN $1978-3000$

\title{
Komposisi Nutrisi Pasta Berbahan Baku Nikumi Kuda dan Sapi
}

\author{
Composition of Paste Nutrition Made From Horse and Beef Nikumi (Surimi-Like) \\ Olfa Mega \\ Jurusan Peternakan Fakultas Pertanian Universitas Bengkulu \\ Jalan Raya Kandang Limun, Bengkulu. Telp. (0736) 2170 pst.219.
}

\begin{abstract}
The objective of the research was to study nutrients composition of horse and beef nikumi (surimi-like) pastes. A completely block randomized design with two factorial were used to arrange the treatments. First factor was meat (horse and beef meat) and another one was sum of leaching (0, 3, 6, 9 times). Data were analyzed using ANOVA and were tested by Least Square Means (LSMeans). The results showed that leaching decreased fat, protein, salt soluble protein content of paste significantly and increased carbohydrate one but did not affect ash content significantly. The decreasing percentage of fat contents in 3,6 and 9 times leaching were 15,96\%;29,16\% and $42,12 \%$ respectively, the protein were $13,14 \% ; 24,56 \%$ and $29,35 \%$; and The salt soluble protein were 13,53 ; 28,15 and 67,64 . the carbohydrate increase $28,35 \% ; 88,57 \%$ and $120,35 \%$ from leaching 0 times.
\end{abstract}

Key words : Leaching, nutriens, nikumi pastes

\begin{abstract}
ABSTRAK
Penelitian bertujuan untuk mengevaluasi komposisi nutrisi pasta berbahan baku nikumi kuda dan sapi. Penelitian menggunakan rancangan acak kelompok pola faktorial, faktor 1 terdiri dari jenis daging (daging kuda dan daging sapi) dan faktor 2 terdiri dari jumlah leaching (0,3,6 dan 9) kali. Data dianalisis dengan anova uji lanjut menggunakan Least square means (LSMeans). Hasil penelitian menunjukkan pencucian (leaching) nyata $(\mathrm{P}<0,05)$ menurunkan kadar lemak, protein, protein larut garam dan meningkatkan karbohidrat pasta tetapi tidak nyata meningkatkan kadar abu pasta. Persentase penurunan kadar lemak berturut-turut pada pencucian 3, 6 dan 9 kali adalah $15,96 \% ; 29,16 \%$ dan $42,12 \%$ untuk kadar protein adalah $13,14 \% ; 24,56 \%$ dan $29,35 \%$ serta untuk kadar ssp adalah $13,53 \% ; 28,15 \%$ dan $67,64 \%$. Karbohidrat meningkat $28,35 \%, 88,57 \%$ dan $120,35 \%$ dibanding tanpa pencucian.
\end{abstract}

Kata-kata kunci: Pencucian, nutrisi, pasta nikumi.

\section{PENDAHULUAN}

Ternak kuda mempunyai potensi yang cukup besar sebagai penghasil daging. Populasi ternak kuda di Indonesia tahun 2008 mencapai 411.464 ekor, populasi terbesar terdapat pada propinsi Sulawesi Selatan, Nusa Tenggara Timur, Nusa Tenggara Barat dan Jawa Timur. Produksi daging kuda dari tahun 2004 s/d 2008 meningkat yaitu 1.569 ton tahun 2004, 1.591 ton tahun 2005, 2.267 tahun 2006, 1.976 ton tahun 2007 dan 2.460 ton tahun 2008 (Ditjenak, 2009).

Di Amerika daging kuda banyak diminati karena kandungan proteinnya yang tinggi, rendah lemak, cita rasa yang agak manis dan mempunyai karakteristik cita rasa antara daging sapi dan daging rusa serta diketahui mempunyai keempukan yang lebih baik dari daging sapi (Evanovsky dan Foster, 1997), namun di Indonesia, konsumsi daging kuda belum sepopuler daging sapi, kambing, domba dan ternak unggas. Hal ini dipengaruhi oleh faktor budaya, rasa dan aroma daging kuda 
yang sangat amis. Disamping faktor-faktor tersebut penerimaan daging kuda di Indonesia sebagai daging konsumsi kemungkinan berkaitan dengan kualitas yang rendah karena ternak kuda dipotong pada umur relatif tua. Ternak kuda umumnya dimanfaatkan untuk kepentingan rekreasi, olahraga, tenaga kerja dalam pertanian dan sarana transportasi, akibatnya kuda yang dipotong adalah kuda yang tidak produktif lagi digunakan dalam kepentingan tersebut.

Daging kuda yang berasal dari ternak yang relatif tua berwarna merah gelap karena kandungan mioglobinnya tinggi akibat dipekerjakan dalam waktu yang relatif lama. Meskipun sudah diolah menjadi produk sosis warna sosis yang dihasilkan lebih gelap dari sosis yang menggunakan bahan dasar daging sapi sehingga kurang disukai (Agawati, 2003). Disamping itu daging kuda mempunyai flavor khas (off flavor) yang kurang disukai, flavor ini sangat berperan dalam mempengaruhi pemilihan dan kesukaan konsumen akan makanan. Prekursor dari flavor daging adalah komponen yang larut dalam air (asam amino, peptida, karbohidrat, nukleotida, tiamin ) dan lipid. Oleh sebab itu diupayakan untuk menghilangkan flavor dan warna yang gelap tersebut dengan proses leaching atau pencucian dengan air dingin.

Leaching adalah proses pencucian daging ikan yang diterapkan pada teknologi pembuatan surimi. Surimi adalah istilah dalam bahasa Jepang untuk nama suatu produk yang berasal dari daging ikan (nikumi untuk produk yang berasal dari daging) yang sudah dipisahkan dari tulang-tulangnya, digiling secara mekanis dan dicuci beberapa kali dengan air dingin sehingga bau dan warnanya menjadi lebih baik. Surimi merupakan bahan antara untuk diolah menjadi produk-produk lanjutan yang membutuhkan sifat elastisitas daging ikan seperti kamaboko, bakso ikan, sosis ikan dan lain-lain (Lanier dan Lee, 1981). Tujuan dari leaching adalah untuk memisahkan lemak, darah, pigmen, garam-garam anorganik, protein dan enzim yang larut dalam air dan kontaminan sehingga kemampuan daging untuk membentuk gel meningkat akibat meningkatnya konsentrasi aktomyosin. Banyaknya protein, lemak, mineral dan karbohidrat yang terpisah selama leaching dan yang terdapat pada produk pasta berbahan baku nikumi akan dievaluasi dalam penelitian ini.

Pasta adalah suatu produk pangan yang berbentuk emulsi dan dibuat dari bahan utama daging, pati dan lemak. Ada dua jenis emulsi makanan yang penting yaitu sistem emulsi yang bersifat elastis dan sistem emulsi yang bersifat plastis. Emulsi makanan yang bersifat elastis adalah makanan yang mempunyai tekstur kenyal contohnya, sosis, bakso, meat loaf dan lain-lain. Emulsi makanan yang bersifat plastis adalah jenis makanan yang dapat diolesken contohnya, mentega, pasta ikan dan "liver pasta" dan umumnya dimakan bersama-sama roti.

Pasta merupakan salah satu produk daging olahan yang dapat dijadikan alternatif untuk dikembangkan sebagai pangan yang bergizi. Pembuatan pasta dari daging yang telah mengalami proses pencucian yang berulang-ulang dan dibekukan diduga akan mempengaruhi komposisi nutrisinya, untuk itu dilakukan penelitian tentang pengaruh pencucian terhadap komposisi nutrisi pasta.

\section{MATERI DAN METODE}

Bahan yang digunakan dalam penelitian ini adalah daging sapi dan daging kuda, sukrosa, sorbitol dan polifosfat yang digunakan sebagai krioprotektan, CMC, susu skim, bumbu (foeli, merica, ketumbar, jahe, bawang merah, bawang putih, garam, gula, monosodium glutamat (MSG)), es batu dan bahan-bahan lain yang digunakan untuk analisa kimia.

Peralatan yang digunakan antara lain alat penggiling daging ( food processor), meat mincer, termometer, blender, timbangan, kompor, pisau, dandang, autoclave, botol selai, wadah plastik dan peralatan lain yang digunakan dalam analisis dan pengambilan data peubah. 
ISSN $1978-3000$

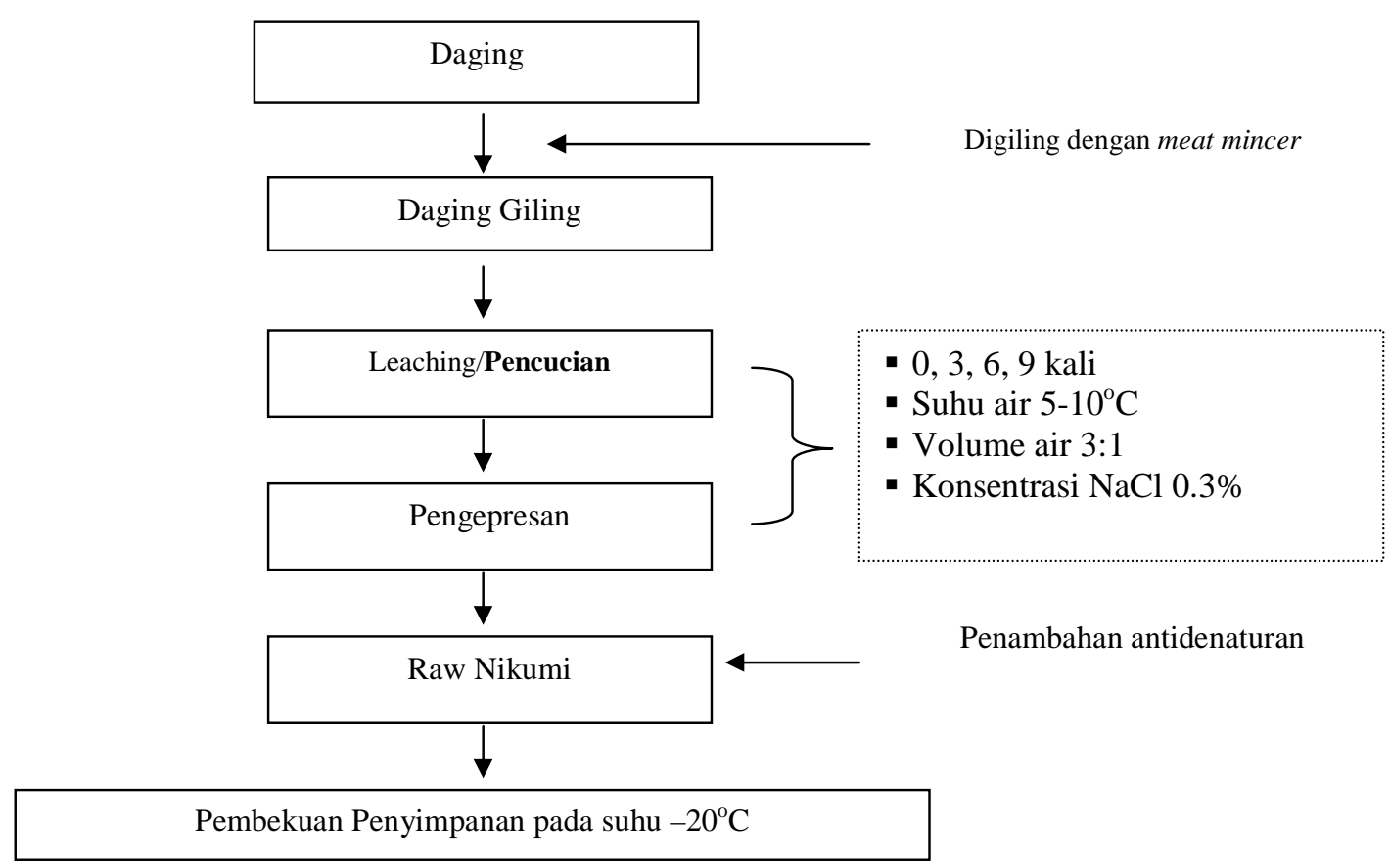

Gambar 1. Diagram alir pembuatan nikumi

\section{Metode Penelitian}

\section{Perlakuan Leaching.}

a. Daging sapi dan daging kuda dipisahkan dari lemak dan jaringan ikat, kemudian digiling dengan menggunakan meat mincer.

b. Daging giling (minced meat) untuk satu ulangan ditimbang seberat $400 \mathrm{~g}$.

c. Dilakukan leaching sesuai dengan perlakuan;

- Perlakuan P0 tidak dilakukan leaching.

- Perlakuan P1 menggunakan air 2 kali dilanjutkan dengan air garam 1 kali.

- Perlakuan P2 dengan air 5 kali dilanjutkan dengan air garam 1 kali

- Perlakuan P3 dengan air 8 kali dilanjutkan dengan air garam 1 kali

d. Air dalam daging dikeluarkan dengan cara penyaringan atau pengepresan dengan kain kasa dengan ukuran poripori \pm 35 mesh. e. Tambahkan antidenaturan (4 \% sukrosa, $4 \%$ sorbitol , 0,2 \% polifosfat) dan campur dengan menggunakan food processor.

f. Nikumi dikemas dengan plastik polietilen dan segera disimpan dalam freezer yang bersuhu $-20^{\circ} \mathrm{C}$.

g. Nikumi digunakan sebagai bahan dasar pembuatan pasta.

\section{Pembuatan Pasta}

Dalam penelitian ini dilakukan pembuatan pasta dengan menggunakan bahan dasar nikumi beku dari percobaan tahap pertama.

Tahap-tahap pembuatan pasta adalah sebagai berikut :

a. Nikumi sapi atau kuda dithawing, lalu dikukus \pm 20 menit.

b. Bumbu-bumbu ditimbang ditempat terpisah sesuai dengan komposisi, dihaluskan dan dicampur hingga rata.

c. Emulsi antara minyak, air dan skim dibuat sampai homogen.

d. Bahan a, b dan c dicampur sampai terbentuk campuran yang homogen. 
ISSN $1978-3000$

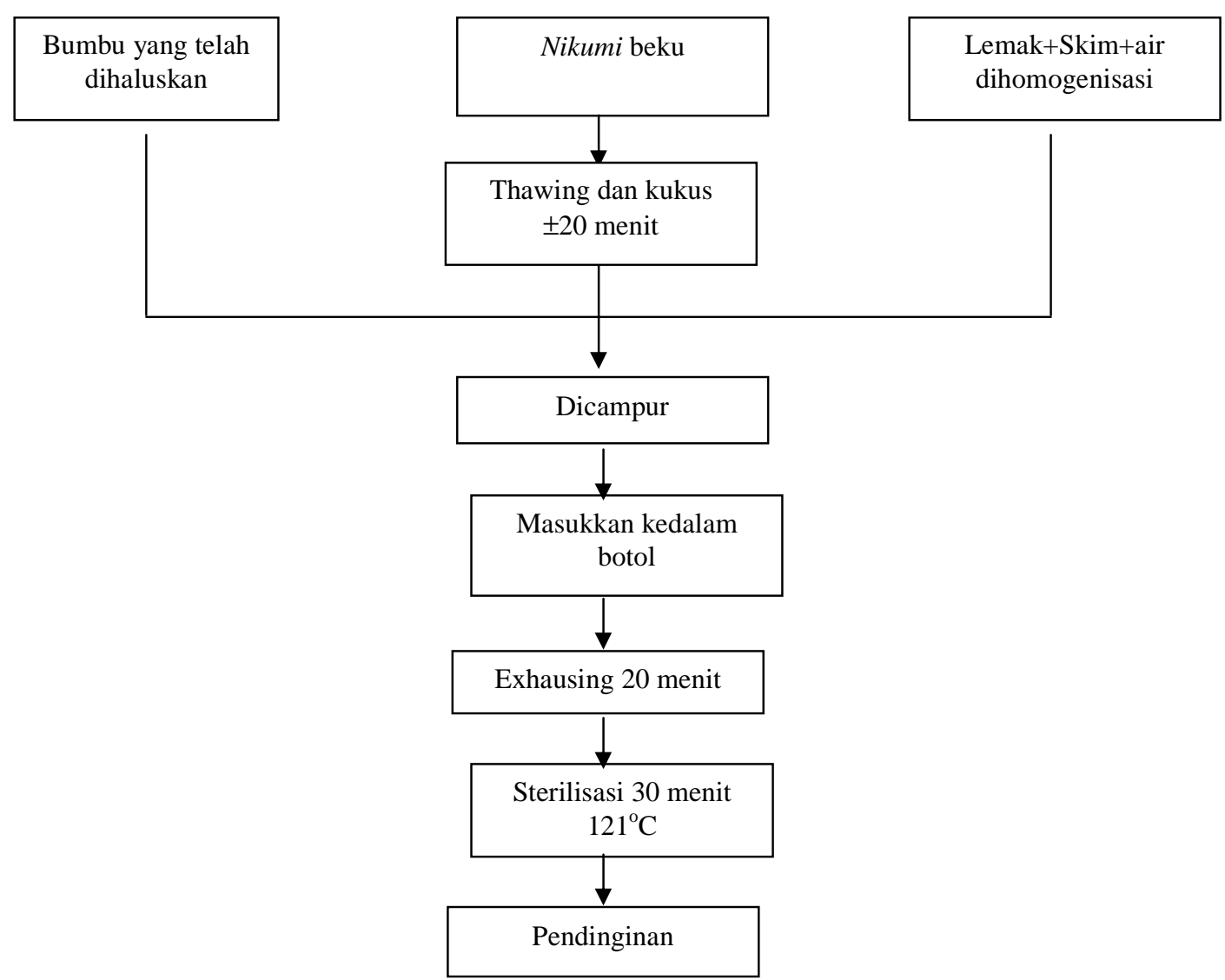

Gambar 2. Diagram alir pembuatan pasta

e. Adonan yang sudah tercampur dimasukkan kedalam botol.

f. Dilakukan pengukusan (exhausing) selama 20 menit.

g. Pasta disterilisasi pada suhu $121^{\circ} \mathrm{C}$ selama 30 menit dalam autoclave.

h. Pasta didinginkan

Komposisi bahan-bahan dalam pembuatan pasta (\% dari bobot daging) adalah sebagai berikut: a) Bahan emulsi terdiri dari skim 20\%, minyak sayur $15 \%$, air $60 \%$, b) Bumbu terdiri dari sukrosa 0,2\%, garam 1,5\%, MSG 0,2\%, CMC 2,5\%, foeli 0,2\%, merica 0,5\%, ketumbar $0,2 \%$, jahe $0,5 \%$ dan bawang putih $0,5 \%$.
Peubah yang diamati adalah kadar air, abu, protein, lemak, protein larut garam dan karbohidrat.

\section{Rancangan Percobaan}

Percobaan ini menggunakan rancangan acak kelompok dengan pola faktorial $2 \times 4$ dengan tiga kelompok, ulangan sebagai kelompok. Faktor pertama adalah jenis daging yang terdiri dari daging sapi dan daging kuda, dan faktor kedua adalah jumlah ulangan pencucian yaitu 0 , 3, 6 dan 9 kali..

Untuk menguji pengaruh perlakuan terhadap peubah yang diamati dilakukan analisis ragam dengan menggunakan prosedur General Linier Models (GLM) dari Statistical Analysis System (SAS) Program. Apabila hasil analisis ragam menunjukkan perbedaan yang 
nyata dilanjutkan dengan Least Square Means (LSM) (Stell dan Torrie, 1995).

\section{HASIL DAN PEMBAHASAN}

Komposisi nutrisi pasta nikumi kuda dan sapi ditampilkan dalam Tabel 1.

\section{Kadar Air}

Air merupakan senyawa yang sangat penting dalam struktur emulsi pasta. Kandungan air dalam pasta sangat mempengaruhi tekstur pasta tersebut. Kadar air pasta nikumi sapi dan kuda berkisar antara $64,63 \%$ sampai $69,40 \%$, kadar air pasta rata-rata adalah 66,97\%. Hasil analisis ragam menunjukkan jenis daging berpengaruh sangat nyata $(\mathrm{P}<0,01)$ terhadap kadar air nikumi, sedangkan frekuensi pencucian tidak berpengaruh nyata $(\mathrm{P}>0,05)$. Tidak terjadi interaksi antara jenis daging dan frekuensi pencucian terhadap kadar air pasta nikumi. Kadar air pasta nikumi kuda nyata lebih tinggi $(68,42 \%)$ dibanding pasta nikumi sapi $(65,52 \%)$.
Perbedaan ini disebabkan oleh antara lain kandungan air nikumi kuda (70,60\%) sebagai bahan baku pembuatan pasta lebih tinggi dari nikumi sapi (68,01\%) (Mega, 2006). Kadar air pasta meningkat cenderung meningkat jika dibandingkan dengan kadar air nikumi sebagai bahan baku. Besarnya peningkatan disajikan pada Tabel 2. Peningkatan kadar air disebabkan karena adanya penambahan air pada saat pembuatan pasta yaitu $60 \%$ dari berat nikumi. Meskipun penambahan air cukup besar namun pada Tabel 2 kisaran peningkatan kadar air adalah $0,63 \%-3,35 \%$ hal ini dikarenakan terjadinya penguapan pada proses exhausing dan sterilisasi.

\section{Kadar Abu}

Hasil analisis ragam menunjukkan bahwa kadar abu pasta nikumi kuda dan sapi sangat nyata $(\mathrm{P}<0,01)$ dipengaruhi oleh jenis daging, sementara frekuensi pencucian tidak memberikan pengaruh yang nyata $(\mathrm{P}>0,5)$. Tidak terjadi interaksi antara kedua faktor terhadap kadar abu. Kadar abu pasta nikumi kuda (3,98\%) nyata lebih tinggi dibanding dari

Tabel 1. Rataan hasil analisis kimia pasta nikumi kuda dan sapi berdasarkan $100 \%$ bahan kering.

\begin{tabular}{|c|c|c|c|c|c|c|}
\hline \multirow[t]{2}{*}{ Peubah (\%) } & \multirow[t]{2}{*}{ Jenis Daging } & \multicolumn{4}{|c|}{ Frekuensi Pencucian (kali) } & \multirow[t]{2}{*}{ Rerata } \\
\hline & & 0 & 3 & 6 & 9 & \\
\hline \multirow[t]{3}{*}{ Air } & Kuda & 68,58 & 69,40 & 67,20 & 68,49 & $68,42^{a}$ \\
\hline & Sapi & 65,99 & 64,93 & 64,63 & 66,52 & $65,52^{b}$ \\
\hline & Rataan & 67,29 & 67,17 & 65,91 & 67,51 & 66,97 \\
\hline \multirow[t]{3}{*}{ Kadar Abu } & Kuda & 3,95 & 3,95 & 3,98 & 4,02 & $3,98^{\mathrm{A}}$ \\
\hline & Sapi & 2,95 & 3,31 & 3,34 & 3,44 & $3,26^{\mathrm{B}}$ \\
\hline & Rataan & 3,45 & 3,63 & 3,66 & 3,73 & 3,56 \\
\hline \multirow[t]{3}{*}{ Kadar Lemak } & Kuda & $25,67^{a}$ & $20,09^{c}$ & $16,14^{\mathrm{d}}$ & $12,57^{\mathrm{e}}$ & $18,62^{\mathrm{A}}$ \\
\hline & Sapi & $25,09^{a}$ & $22,57^{b}$ & $19,82^{c}$ & $16,82^{\mathrm{d}}$ & $21,08^{\mathrm{B}}$ \\
\hline & Rataan & $25,38^{\mathrm{A}}$ & $21,33^{\text {в }}$ & $17,98^{\mathrm{C}}$ & $14,69^{\mathrm{D}}$ & 19,85 \\
\hline \multirow[t]{3}{*}{ Kadar Protein } & Kuda & $51,82^{\mathrm{b}}$ & $46,98^{c}$ & 38,13 ef & $36,23^{\mathrm{f}}$ & $43,29 A$ \\
\hline & Sapi & $55,51^{a}$ & $46,23^{c}$ & $42,83^{\mathrm{d}}$ & $39,60^{\mathrm{e}}$ & $46,04^{\mathrm{B}}$ \\
\hline & Rataan & $53,66^{\text {A }}$ & $46,61^{\text {в }}$ & $40,48^{\mathrm{C}}$ & $37,91^{\mathrm{D}}$ & 44,66 \\
\hline Kadar Protein & Kuda & $5,39^{a}$ & $4,65^{\mathrm{b}}$ & $3,63^{\mathrm{d}}$ & $0,30^{\mathrm{f}}$ & $3,49^{\mathrm{A}}$ \\
\hline \multirow[t]{2}{*}{ Larut Garam } & Sapi & $5,55^{\mathrm{a}}$ & $4,81^{\mathrm{b}}$ & $4,22^{c}$ & $3,24^{\mathrm{e}}$ & $4,45^{\mathrm{B}}$ \\
\hline & Rataan & $5,47^{\mathrm{A}}$ & $4,73^{\mathrm{в}}$ & $3,93^{C}$ & $1,77^{\mathrm{D}}$ & 3,97 \\
\hline Kadar & Kuda & 23,46 & 25,56 & 38,38 & 44,38 & $32,95^{\mathrm{A}}$ \\
\hline \multirow[t]{2}{*}{ Karbohidrat } & Sapi & 13,31 & 21,62 & 30,94 & 36,62 & $25,62^{\mathrm{B}}$ \\
\hline & Rataan & $18,38^{\text {a }}$ & 23,59 a & $34,66^{\mathrm{b}}$ & $40,50^{\text {b }}$ & 29,28 \\
\hline
\end{tabular}

Jurnal Sain Peternakan Indonesia Vol. 3, No 2. Juli - Desember 2008 
pasta nikumi sapi (3,26\%). Perbedaan kandungan abu pada pasta ini dipengaruhi oleh kandungan abu nikumi dari kedua jenis daging ini. Kadar abu nikumi kuda adalah 3,38\% dan nikumi sapi 2,83\% (Mega, 2006) sehingga kandungan abu dalam produk pasta yang menggunakan bahan baku nikumi tersebut juga berbeda karena komposisi bahan lain dalam pembuatan pasta sama pada semua perlakuan. Terjadi penurunan kadar abu dari nikumi menjadi pasta, besarnya penurunan berkisar antara 0,46\% - 0,76\%. Penurunan ini diduga karena adanya perubahan komposisi bahan yaitu adanya penambahan bahan pembuatan pasta sehingga persentase kadar abu terhadap total bahan menurun.

\section{Kadar Lemak}

Jenis daging dan frekuensi pencucian sangat nyata $(\mathrm{P}<0.01)$ mempengaruhi kadar lemak pasta nikumi kuda dan sapi, dan terdapat interaksi antara kedua faktor tersebut. Kadar lemak pasta nikumi kuda nyata lebih rendah (18,62\%) dibanding pasta nikumi sapi $(21,08 \%)$ dengan kisaran kadar lemak pada kedua jenis daging ini antara 12,57\% sampai 25,67\%.

Frekuensi pencucian nyata menurunkan kandungan lemak pasta nikumi, karena sebagian lemak hilang dengan adanya pencucian, semakin banyak frekuensi pencucian lemak yang hilang semakin banyak. Penambahan minyak sebanyak $15 \%$ dari bobot bahan utama yaitu nikumi pada proses pembuatan pasta berguna untuk membentuk emulsi dengan air dan susu skim. Penambahan lemak nabati tersebut sama jumlahnya pada setiap perlakuan, sehingga pola penurunan kadar lemak pasta sama dengan penurunan kadar lemak nikumi. Persentase penurunan kadar lemak berturut-turut pada pencucian 3, 6 dan 9 kali adalah 15,96\%; 29,16\% dan 42,12\% dibanding tanpa pencucian.

\section{Kadar Protein}

Sterilisasi panas menyebabkan terjadinya koagulasi protein dan kehilangan asam amino sekitar 10-20\% (Fellows, 2000). Jenis daging dan frekuensi pencucian sangat nyata $(\mathrm{P}<0,01)$ mengaruhi kadar protein dalam pasta nikumi kuda dan sapi, tetapi tidak terjadi interaksi antara kedua faktor ini terhadap kadar protein pasta nikumi. Kandungan kadar protein pasta berkisar antara 36,23\% - 55,51\%. Rataan kandungan protein pasta nikumi kuda adalah $43,29 \%$ sedangkan pasta nikumi sapi rata-rata $46,04 \%$. Tingginya kandungan protein

Tabel 2. Penurunan komposisi nutrisi pasta kuda dan sapi dari bahan baku nikumi.

\begin{tabular}{llcccc}
\hline Peubah & Jenis & \multicolumn{4}{c}{ Frekuensi Pencucian (kali) } \\
\cline { 2 - 6 } A ir & Daging & 0 & 3 & 6 & 9 \\
& Kuda & -2.65 & -0.63 & -3.03 & -2.41 \\
\hline Abu & Sapi & -1.54 & -3.21 & -3.35 & -1.88 \\
\hline Lemak & Kuda & 0.52 & 0.76 & 0.54 & 0.57 \\
& Sapi & 0.46 & 0.56 & 0.68 & 0.73 \\
\hline Protein & Kuda & 16.14 & 13.34 & 11.26 & 9.89 \\
& Sapi & 11.69 & 11.91 & 13.04 & 13.29 \\
\hline Protein Larut Garam & Kuda & -28.09 & -22.15 & -22.83 & -21.79 \\
& Sapi & -21.34 & -26.15 & -26.08 & -23.27 \\
\hline Karbohidrat & Sapi & -2.48 & -1.7 & -1.38 & -2.25 \\
& Kuda & -1.54 & -1.8 & -0.65 & 0.47 \\
\hline
\end{tabular}

Keterangan : - = meningkat 
pasta nikumi sapi disebabkan oleh kandungan protein nikumi sapi 70,25\% dibanding nikumi kuda 67,01\% (Mega, 2006). Terjadi penurunan kadar protein dari bahan baku nikumi menjadi pasta nikumi, besarnya penurunan ini adalah $30,67 \%$ untuk pasta nikumi kuda dan 29,50\% untuk pasta nikumi sapi, penurunan ini tidak termasuk sumbangan protein dari susu skim yang ditambahkan sebanyak $20 \%$ dalam pembuatan pasta. Turunnya kandungan protein diduga akibat terjadinya denaturasi protein selama proses pemanasan baik pada tahap exhausing maupun pada proses sterilisasi. Menurut Fellows (2000), sterilisasi terhadap daging kaleng menyebabkan terjadinya perubahan tekstur yang disebabkan oleh koagulasi protein dan kehilangan kemampuan protein dalam mengikat air, hal ini menyebabkan terjadinya pengkerutan dan pengerasan jaringan otot. Frekuensi pencucian nyata menurunkan kadar protein pasta. Kadar protein pasta nikumi adalah 53,66\%, 46,61\%, $40,48 \%$ dan $37,91 \%$ berturut-turut untuk pasta tanpa pencucian, pencucian 3 kali, 6 kali dan 9 kali. Persentase penurunan kadar protein berturut-turut pada pencucican 3, 6 dan 9 kali adalah $13,14 \% ; 24,56 \%$ dan $29,35 \%$

\section{Kadar Protein Larut Garam (Salt soluble protein $=s s p$ )}

Kadar protein larut garam (ssp) sangat nyata $(\mathrm{P}<0,01)$ dipengaruhi oleh jenis daging, frekuensi pencucian dan terjadi interaksi antara kedua faktor tersebut. Rata-rata kadar ssp pasta nikumi kuda adalah 3,49\% nyata lebih rendah dari ssp pasta nikumi sapi $4,45 \%$, frekuensi pencucian nyata menurunkan $s s p$ pasta. Ssp terdiri dari sebagian protein sarkoplasmik dan protein struktur atau protein fibril. Protein fibril mengandung $32-38 \%$ myosin, $13-17 \%$ aktin, $7 \%$ tropomyosin dan $6 \%$ protein stroma. Kelarutan protein salah satunya dipengaruhi oleh suhu dengan peningkatan suhu antara 0 sampai $40-50^{\circ} \mathrm{C}$. Pada temperatur yang lebih tinggi kelarutan protein berkurang. Perlakuan panas dan denaturasi protein menyebabkan turunnya kelarutan protein (Zayas, 1997). Persentase penurunan berturut-turut pada pencucican 3, 6 dan 9 kali untuk kadar ssp adalah $13,53 \% ; 28,15 \%$ dan $67,64 \%$.

\section{Kadar karbohidrat}

Frekuensi pencucian sangat nyata $(\mathrm{P}<0,01)$ mempengaruhi kadar karbohidrat pasta, jenis daging berpengaruh nyata $(\mathrm{P}<0,05)$ tetapi tidak terdapat interaksi antara keduanya. Pada proses pembuatan nikumi ditambahkan bahan antidenaturasi atau krioprotektan yaitu sukrosa dan sorbitol, kedua bahan tersebut termasuk golongan karbohidrat. Penambahan krioprotektan ini akan meningkatkan kandungan karbohidrat nikumi. Disamping itu peningkatan kadar karbohidrat terjadi karena adanya komponen larut air yang terpisah selama proses pencucian sehingga persentase karbohidrat meningkat terhadap berat daging. Rata-rata kandungan karbohidrat pasta nikumi kuda adalah $32,94 \%$ dan pasta nikumi sapi $25,62 \%$. Pencucian nyata meningkatkan kandungan karbohidrat pasta berturut-turut untuk leaching 0, 3, 6 dan 9 kali adalah 18,38\%, $23,59 \%, \quad 34 \%$ dan 40,50\%. Karbohidrat meningkat berturut-turut untuk pencucian 3, 6 dan 9 kali adalah $28,35 \%, 88,57 \%$ dan $120,35 \%$ dibanding tanpa pencucian.

\section{SIMPULAN}

Pencucian nyata menurunkan kadar lemak, protein dan protein larut garam dan meningkatkan karbohidrat pasta tetapi tidak nyata meningkatkan kadar abu pasta. Persentase penurunan kadar lemak berturutturut pada pencucican 3, 6 dan 9 kali adalah 15,96\%; $29,16 \%$ dan $42,12 \%$ untuk kadar protein adalah 13,14\%; $24,56 \%$ dan $29,35 \%$ serta untuk kadar protein larut garam adalah $13,53 \% ; \quad 28,15 \%$ dan $67,64 \%$. Karbohidrat meningkat $28,35 \%, \quad 88,57 \%$ dan $120,35 \%$ dibanding tanpa pencucian.

\section{DAFTAR PUSTAKA}

Aberle, E.D., J.C. Forrest, D.E Gerrard and E.W.Mills. 2001. Principles of Meat 
ISSN $1978-3000$

Science. Fourth Ed. Kendal/Hunt Publishing Company, Amerika.

Agawati. 2003. Sifat fisiko-kimia sosis daging kuda dan sapi dengan substitusi kasein oleh isolat protein kedelai sebagai binder [tesis]. Institut Pertanian Bogor, Bogor.

[Dijenak] Direktorat Jenderal Bina Produksi Peternakan Departemen Pertanian. 2008. Buku Statistik Peternakan 2008. Ditjenak. Jakarta.

Emanovsky, S dan J. Foster. 1997. USDA promotes horse and goat meat. http://www.igha.org/USDA.htm [20 Februari 2004].

Fellows, P. J. 2000. Food Processing Technology Principle and Practice. Second Ed.
Woodhead Publishing Limited, Cambridge England.

Lanier, T.C dan C.M. Lee. 1981. Surimi Technology. Marcel Dekker, New York.

Mega, O. 2006. Rendemen dan perubahan nilai gizi nikumi kuda dan sapi pada proses pembuatan nikumi. Jurnal Ilmiah IlmuIlmu Peternakan Vol.VIII (3):155-164.

Steel, R.G.D dan J.H Torrie. 1995. Prinsip dan Prosedur Statistik. Suatu Pendekatan Biometrik. Edisi Kedua. Gramedia, Jakarta.

Zayas, J.F. 1997. Functionality of Protein in Food. Springer, Berlin. 